\title{
MONITORING OF TRANSPORTATION NETWORK OF CARBONIZATION GASES IN COGENERATION PROJECTS ${ }^{1}$
}

\author{
Angélica de Cássia Oliveira Carneiro ${ }^{2 *}$, Danilo Barros Donato ${ }^{2}$, Augusto Rodrigues Valência $^{3}$, Daniel \\ Camara Barcellos ${ }^{4}$, Claudio Homero Ferreira Silva ${ }^{5}$ and Wanderley Luiz Paranaiba Cunha ${ }^{6}$
}

\footnotetext{
${ }^{1}$ Received on 08.10.2015 accepted for publication on 28.06.2017.

${ }^{2}$ Universidade Federal de Viçosa, Departamento de Engenharia Florestal, Viçosa, MG-Brasil. E-mail: <cassiacarneiro1@gmail.com>. and $<$ danilobdonato@gmail.com>.

${ }^{3}$ Biomtec, Biomassas e Tecnologia, Belo Horizonte, MG-Brasil. E-mail: <augusto.biomtec@gmail.com>.

${ }^{4}$ Faculdade Pitágoras de Teixeira de Freitas, Teixeira de Freitas, BA-Brasil. E-mail: < daniel@barcelloscamara.com.br>.

${ }^{5}$ Companhia Energética de Minas Gerais, Belo Horizonte, MG-Brasil. E-mail: <chomero@cemig.com.br>.

${ }^{6}$ Arcelor Bioflorestal, Belo Horizonte, MG-Brasil. E-mail: <wanderley.cunha@amcontratos.com.br>.

*Corresponding author.
}

\begin{abstract}
The goal of this study was to evaluate the performance and efficiency of a transmission system of carbonization gas to the combustion chamber of a burner. The gas transportation network (GTN) consists of removing the gases from the chimney of the furnaces, which pass through pipes until they reach the burner. A heating system was built surrounding the pipe that leads the carbonization gases to avoid the condensation of gases and the generation of wastewater in the pipes. These gases were named trace gases and guided in the opposite direction to the carbonization gases. This study monitored of the temperature of the GTN by analyzing different points of the process with thermocouples attached on the pipes. The correlation between the various temperatures in the sampling points determined the Pearson's correlation coefficient to $95 \%$ of probability and a regression between the variables that had a significant association. The average temperature of carbonization gases in the chimney outlet was $116^{\circ} \mathrm{C}$, and it entered the burner with an average temperature of $166.7^{\circ} \mathrm{C}$, providing an increase of $50.7^{\circ} \mathrm{C}$ on the temperature. The average temperature in the burner chimney outlet for trace gas was $218.35^{\circ} \mathrm{C}$, and it was released to the atmosphere with a temperature of $125.2^{\circ} \mathrm{C}$. The thermal loss was $93.15^{\circ} \mathrm{C}$. The GTN that uses trace gas is presented as an alternative to the flow of gas carbonization. This system is effective regarding non-condensing gases through the pipes, allowing a better use of energy and avoiding the generation of undesirable effluents.
\end{abstract}

Keywords: Chimney; Tubing; Combustion chamber.

\section{MONITORAMENTO DE TRANSPORTE DE GASES DA CARBONIZAÇÃO PARA PROJETOS DE COGERAÇÃO}

\begin{abstract}
RESUMO - O objetivo desse trabalho foi avaliar o desempenho e a eficiência de um sistema de transporte de gases da carbonização até um queimador. O sistema de transporte de gases da carbonização consiste na retirada destes da chaminé dos fornos, os quais passam por tubulações até atingirem o queimador. Para evitar a condensação dos gases e geração de efluentes líquidos, construiu-se um sistema que circunda e aquece a tubulação que conduz os gases da carbonização. Estes foram denominados gases de traço e são conduzidos no sentido oposto aos gases da carbonização. Foi feito um monitoramento da temperatura da rede de transporte dos gases em diferentes pontos de coleta utilizando termopares. Foram determinadas as correlações existentes entre os diferentes pontos de coletas de temperaturas por meio do coeficiente de correlação de Pearson a 95\% de probabilidade e determinado uma regressão entre essas variáveis que apresentaram correlações significativas. A temperatura média dos gases da carbonização na saída da chaminé foi de $116^{\circ} \mathrm{C}$ e o mesmo entrou no queimador com a temperatura média de $166,7^{\circ} \mathrm{C}$, proporcionando um acréscimo de temperatura de $50,7^{\circ} \mathrm{C}$. A temperatura média na saída da chaminé do queimador para o gás de traço foi
\end{abstract}


de $218,35^{\circ} \mathrm{C}$ e o mesmo foi lançado para atmosfera a $125,2^{\circ} \mathrm{C}$, tendo portando uma perda térmica de $93,15^{\circ} \mathrm{C}$. Conclui-se que o sistema de transporte de gases utilizando gás de traço foi eficiente no que concerne a não condensação dos gases da carbonização, permitindo um melhor aproveitamento energético dos mesmos e evitando a geração de efluentes líquidos indesejáveis.

Palavras-Chave: Chaminé; Dutos; Câmara de combustão.

\section{INTRODUCTION}

Brazil is the only country that produces charcoal in large scale to be used in the industry. The country is the largest producer and consumer of charcoal (ABRAF, 2012). Most of the charcoal consumption is for the domestic market, mainly in the State of Minas Gerais, which uses $83.45 \%$ in the steel and pig iron industry, and $14.83 \%$ in the iron alloy industry. The other uses encompass residential use (cooking and heating), industrial use (excluding steel industry) as cement manufacturing process, chemical industry, food industry, and ceramic industry.

In 2012 , more than $86 \%$ of the charcoal consumed in the state of Minas Gerais was from eucalyptus forests, reducing the charcoal production with native species in the steel industry, due to the pressure of national and international consumers, and environmental legislation, through new laws and regulations.

Still, the industries that participate or that are integrated into the steel production are increasing the efficiency in carbonization of wood, improving the environmental, economic, and social aspects of the charcoal and steel industry, and bringing more sustainability to the procedures (ABRAF, 2012).

Within this context of sustainability, the use of burners attached to the furnaces to burn carbonization gases has an outstanding effect. These gases are fuels rich in carbon and hydrogen, which under appropriate conditions of temperature and pressure can undergo chemical reactions in the presence of oxygen, resulting in the release of energy in the form of light and heat (Cardoso et al., 2010). Besides, this process also can generate electric energy and reduce the gases emissions that are harmful to the environment.

However, there are technological barriers related to the quality of gases, which are not homogeneous throughout the carbonization process, in addition to their low calorific value. The limitations are higher in situations that use the heat generated to dry wood

Revista Árvore. 2018;42(6):e420601 or to produce electricity. Among these barriers is the transmission of carbonization gases to burn in a furnace, as many of the gases are condensable at temperatures below $150^{\circ} \mathrm{C}$ (Carneiro et al., 2012).

Thus, as the distance between the ovens and the furnace increases, there is a reduction in the temperature of the carbonization gases that lead to their condensation inside the pipes. This fact causes incrustations, clogging and loss of energy for the burner, due to the presence of tar, a chemical compound with a high calorific value. Also, it also allows the condensation of the pyroligneous acid, which reduces the useful life of the system and a possibility of contamination of the soil through the liquid effluents.

One of the greatest challenges to the development of efficient systems for the burning of the carbonization gases is in the process of transporting them to the combustion chambers (or furnaces) in a way that allows the minimal condensation of these gases, as they have a significant amount of water and other condensable substances in their composition. The production of the carbonization gases throughout the production process (controlled combustion of the wood) occurs in a diverse method with different thermal loads during the cycle. It is necessary to have large industrial areas to accommodate the production demand, such as the ovens, the wood piles, and the charcoal produced. Still, the design rules of the carbonization plants impose a long distance for the transportation of these gases (sometimes more than 300 meters), where significant thermal losses can occur. Therefore, two important factors must be studied: the need to ensure the transportation of the gases in long distances, and the potential to eliminate the undesired condensation, by keeping higher temperatures between the production points (kilns) and the points of consumption (combustion chambers).

The general objective of this research was to evaluate the performance and efficiency of a carbonization gas transportation network (GTN) to the combustion chamber

\footnotetext{
Revista Árvore. 2018;42(6):e420601
} 
of a furnace to use the heat generated for cogeneration projects. The specific objectives are to evaluate the efficiency of the use of combustion gases of the burner as trace gases in the carbonization GTN to avoid the condensation of the tar, to obtaining the thermal loss of trace gas along the carbonization GTN, and to find a correlation matrix of the temperatures of the carbonization GTN and the gas burning system.

\section{MATERIALS AND METHODS}

This experiment was conducted at the Unit of Energy Production (UPE) of the company ARCELORMITTAL Bioflorestas, in the Buritis unit, at the city of Martinho Campos in the State of Minas Gerais.

The materials included twelve rectangular masonry furnaces with an internal capacity of $240 \mathrm{~m} 3$ of wood, an average mass flow rate of carbonization gases of each kiln of $32,000 \mathrm{~kg} / \mathrm{h}$, and $32 \%$ of dry charcoal gravimetric yield (dry basis).

Each carbonization cycle had an average duration of 12 days, where four days were used to the carbonization process and eight days to the furnace cooling. In the carbonizations, the average moisture of the wood was $35 \%$, and the diameters of the wood $\operatorname{logs}$ varied from 8 to $20 \mathrm{~cm}$.

The wood species used for carbonization was Eucalyptus spp., with seven years old, grown in a spacing of $3.0 \mathrm{~m}$ by $2.5 \mathrm{~m}$.

\subsection{Description of the gas transportation network}

\subsubsection{Gas transportation network}

The GTN is made of carbon steel pipes that collect the carbonization gases from the twelve ovens and lead them to the combustion chamber of the burner (Figure 1).

The GTN was designed to form a bifurcation, with six ovens installed to the left (Section 1) and six to the right (Section 2). Then, the gases were directed to a single central duct (Section 3), which in turn conduct the gases to the combustion chamber of the burner. Section 1 corresponds to the furnaces 1 to 6 , which is about $82 \mathrm{~m}$ to the junction of the duct that bring the gases to the burner. Section 2 corresponds to furnaces 7 to 12 , which are $82.4 \mathrm{~m}$ from the junction of the duct that brings the gases to the burner, and Section 3 corresponds to the junction of the ducts of the ovens with an extension of $83.4 \mathrm{~m}$. Therefore, the furthest furnace is located at $166.2 \mathrm{~m}$ from the burner.

This configuration was used to reduce the length of the GTN and minimize condensation and thermal losses.

\subsubsection{Transportation of the carbonization gases to the burner}

The transportation of the carbonization gases of the wood was done through pipes with a diameter of $530 \mathrm{~mm}$ and length as described in Figure 2. To transport these gases, an exhaust fan with a power of $29 \mathrm{CV}$ was used, with an exit velocity of $34.2 \mathrm{~m} / \mathrm{s}$, which sucked the gases and inflated them into the combustion chamber of the burner. This extractor was controlled by a frequency inverter to keep the suction pressure constant in the main duct, allowing exhaustion of the carbonization gases along with the entire process.

The exhaustion of the carbonization gases to the pipes of the GTN happened in the upper part of the chimney of each kiln (Figure 1, Detail 1). To control the flow rate of the carbonization gases, a butterfly valve, manually operated, has been installed. This valve could totally or partially close the chimney with only $1 / 4$ turn. The valve allowed to select which phases throughout the carbonization process would go to the gas burners.

The valves were installed to a metal cylinder attached to the top of the furnace chimney at $6.30 \mathrm{~m}$ of height. The control of opening and closing valves was done manually with the help of a steel cable and a counterweight. The steel cable was used to force the opening of the valve providing different amounts of gas capture and consequently flow control for the environment. The counterweight worked as a counterforce that allowed the valves to close or to open.

The operation of the valves was controlled by an axis, which was subject to the flow variations during the process and accumulation of tar. These disturbances can damage the operation of the valves through the years.

A second butterfly valve, controlled by an automatic system, was installed at the end of the duct that connects the furnace chimney to the main gas pipe.

Revista Árvore. 2018;42(6):e420601 


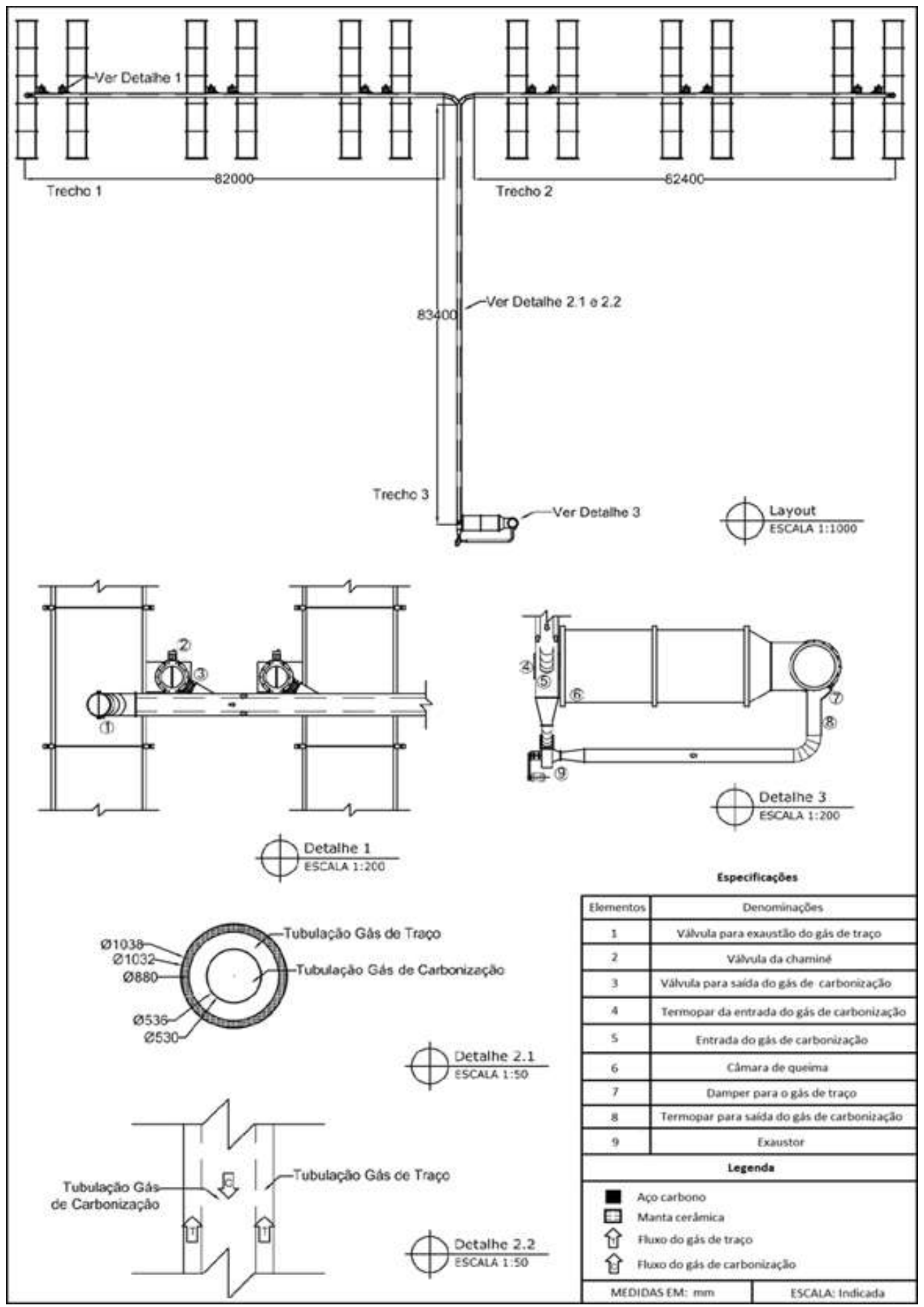

Figure 1 - Layout of the gas transportation network (GTN).

Figura 1 - Layout da rede de transporte dos gases.

Revista Árvore. 2018;42(6):e420601 


\subsubsection{Transportation of trace gas}

To avoid condensation of the gases in the pipes, a system was built to surround and heat the pipe that conducts the carbonization gases. This system was composed of a double pipe heat exchanger, with a diameter of $880 \mathrm{~mm}$, that surrounded the combustion gases of the burner. These gases were called trace gases, and their exhaustion occurred at 3.20 meters of the total height of the chimney. The trace gases were conducted in the opposite direction from the carbonization gases until reaching the outlets of the GTN (Figure 1, Detail 2.2).

For this purpose, an exhaust fan was used, with an engine with a power of $25.6 \mathrm{CV}$, which allowed the circulation of the trace gas at a speed of $18 \mathrm{~m} / \mathrm{s}$, with power and speed lower than the exhaustion of the carbonization gases.

The external pipe that carries the trace gas was externally coated with a ceramic fiber blanket with a density of 160 $\mathrm{kg} / \mathrm{m} 3$ and a thickness of $7.62 \mathrm{~mm}$, to reduce thermal losses and to optimize the operation of the GTN (Figure 1).

After traveling through the GTN, the trace gas is released into the atmosphere through metal ducts installed at the ends of sections 1 and 2 (Figure 1, Detail 1.1).

\subsection{Automatic system for the gas transportation network}

The temperatures of the GTN were monitored by an automatic system with online data collection, tracking the temperature values in real time, and leading to a better control of the cogeneration system. This function creates the possibility to maintain the temperature in the combustion chamber of the carbonization gas burner.

Thermocouples attached through the GTN were used to collect the temperature of the carbonization and trace gases, the combustion chamber, and the burner chimney temperatures.

\subsection{Performance of the gas transportation network}

To evaluate the performance of the wood carbonization in the GTN to be used in cogeneration systems, the temperatures were measured at the sampling points as described in Table 1. The temperatures were monitored along the GTN, using type k thermocouples attached to the pipes.
Table 1 - Temperature of the monitored points by type of gas and sampling site.

Tabela 1 - Pontos de monitoramento da temperatura em função do tipo de gás e local de amostragem.

\begin{tabular}{lc}
\hline Gas & Sampling site \\
\hline & Furnace Chimney $(1-12)$ \\
Carbonization gases & Section 1 \\
& Section 2 \\
& Entrance of the \\
& carbonization gases \\
into the burner \\
\hline Combustion gas - & Bottom of burner \\
Burner Chimney & chimney \\
& Burner chimney outlet \\
\hline & Section 1 \\
Trace gases & Section 2 \\
& Section 3 \\
\hline
\end{tabular}

It is important to highlight that the values for the furnace chimney temperature correspond to the exit temperature of the carbonization gases in the chimney of each furnace in operation on the evaluated day, and the transportation of these gases was only started when their temperature reached over $100^{\circ} \mathrm{C}$. For this type of furnace used in this work, the carbonization cycle is four days. The start temperature was reached around the second day of carbonization, that happens when the process reached the exothermic stage.

The gas temperature monitoring was done by three consecutive runs of the cogeneration, and each data was collected within six-hour intervals for 48 hours.

\subsubsection{Efficiency of the combustion gases}

To evaluate the efficiency of the combustion gases along the GTN, gas samples were initially collected at the different sampling points (Table 1). The values of the thermal energy net of the carbonization gas and the heating of the pipe by the trace gas were measured using the ratio of the temperature of the carbonization gases at the furnaces chimney outlet and their temperature in the entrance of the combustion chamber of the burner.

Later, a correlation analysis was performed between the different gas temperature collection points, to know the significance of the relationship between these variables.

A regression analysis was made to measure the thermal energy net of the carbonization gases in the

Revista Árvore. 2018;42(6):e420601 
different sections along the GTN until their entrance into the combustion chamber of the burner.

\subsubsection{Evaluation of the thermal loss of trace gas along} the gas transportation network.

An analysis was made to evaluate the thermal loss of trace gas along the GTN to measure the difference in temperature at the outlet of the burner chimney and the temperatures in the different sections of the gas until it reached the ends of the GTN process.

The difference between the temperature at the beginning and the end of the trace gas transportation and the thermal loss along the GTN was determined in percentage

\subsection{Statistical analysis}

The Pearson correlation coefficient was used to determine the correlation between the different points of collection of temperatures along the GTN, considering the $95 \%$ probability level. A regression was also determined to find the relationship between variables that have shown significant correlations.

\section{RESULTS}

\subsection{Temperature of the gas transportation network}

Table 2 shows the average values of the temperature of the gases at the different sampling points of the GTN.

The observations showed that the average temperature of the carbonization gases at the exit of the furnace chimney was approximately $116.67^{\circ} \mathrm{C}$, and it reached the combustion chamber of the burner at $166.7^{\circ} \mathrm{C}$, with an increase in temperature of around $50^{\circ} \mathrm{C}$.

\subsection{Correlations between gas temperatures at different sampling points.}

Table 3 shows the correlations between the gas temperatures along the pipes at different sampling points.

Table 3 shows that most of the variables in this study had a positive correlation. However, the average temperature of the carbonization gases at the exit of the chimneys of the furnaces (A1) with the other sampling points of temperature along the GTN did not present a positive correlation.

\subsection{Correlation between trace gas and carbonization gas}

Figure 2 shows the relationships between the trace gas temperature and the carbonization gas temperature at the different sampling points of the GTN.

Figure 2 shows a significant relationship between the temperature of the trace gas and the increase in the temperature of the carbonization gases in the different sections; the higher the trace gas temperature, the higher the carbonization gas temperature.

\section{DISCUSSION}

\subsection{Temperature of the gas transportation network}

Table 2 shows that the trace gas kept the carbonization GTN warm. It provides a higher temperature

Table 2 - Average temperature along the gas transportation network.

Tabela 2 - Temperatura média obtida ao longo da rede de transporte dos gases.

\begin{tabular}{lcc}
\hline Gases & Sampling site & $\begin{array}{c}\text { Average and standard } \\
\text { deviation of the } \\
\text { temperatures }\left({ }^{\circ} \mathrm{C}\right)\end{array}$ \\
\hline & Furnace Chimney $(1-12)$ & $116,70( \pm 16,2)$ \\
$134,0( \pm 24,8)$ \\
Carbonization gases & Section 1 & $137,8( \pm 19,7)$ \\
& Section 2 & $182,3( \pm 7,3)$ \\
& Section 3 & $166,7( \pm 15,6)$ \\
\hline Combustion gas - Burner Chimney & Entrance of the carbonization \\
& gases into the burner & $942,90( \pm 179,53)$ \\
\hline & Bottom of burner chimney & $218,35( \pm 56,43)$ \\
\hline
\end{tabular}

Revista Árvore. 2018;42(6):e420601 
Table 3 - Correlations between the average temperatures of the gases obtained along the pipes.

Tabela 3 - Correlações entre as Temperaturas médias dos gases obtidas longo das tubulações.

\begin{tabular}{lcccccccccc}
\hline & (A1) & (A2) & (A3) & (A4) & (A5) & (A6) & (A7) & (A8) & (A9) & (A10) \\
\hline Carbonization gases at chimney outlets (A1) & - & & & & & & & & \\
Carbonization gases at the sections (A2) & 0,03 & - & & & & & & & \\
Carbonization gases at the burner entrance (A3) & 0,08 & 0.94 & - & & & & & & \\
Combustion gases of the burner (A4) & $-0,07$ & 0.90 & 0.82 & - & & & & & \\
Combusted gases at the burner chimney outlet (A5) & $-0,09$ & 0.88 & 0.95 & 0.78 & - & & & & \\
Average temperature of the trace gas (A6) & 0,10 & 0.95 & 0.97 & 0.86 & 0.93 & - & & & \\
Trace gas at the GTN outlet (A7) & 0,09 & 0.93 & 0.86 & 0.82 & 0.73 & 0.84 & - & & \\
Trace gas at section 1(A8) & 0,05 & 0.95 & 0.86 & 0.84 & 0.78 & 0.85 & 0.95 & - & \\
Trace gas at section 2 (A9) & 0,07 & 0.87 & 0.71 & 0.83 & 0.65 & 0.76 & 0.82 & 0.82 & - \\
Trace gas at section 3 (A10) & $-0,04$ & 0.87 & 0.94 & 0.76 & 0.93 & 0.94 & 0.75 & 0.77 & 0.54 & - \\
\hline
\end{tabular}

*Correlations in red have a $95 \%$ significance level proved by the $t$ test

until the burner and avoids eventual condensation by improving the calorific value of the gas in the combustion chamber. This fact is due to the heat transfer by conduction (de Paula and Cunha, 2013), which means that the energy in the form of heat is transferred from one body to another through the difference of temperatures (Tipler, 1995).
According to Hildebrandt and Battistel (2001), when a warmer body is placed next to a colder body, the kinetic energy vibration is transferred to the molecules of that body and raises its temperature.

The heat difference between the trace gas pipe and the carbonization gas pipe allows that the heat transferred through the external pipe wall and its insulation

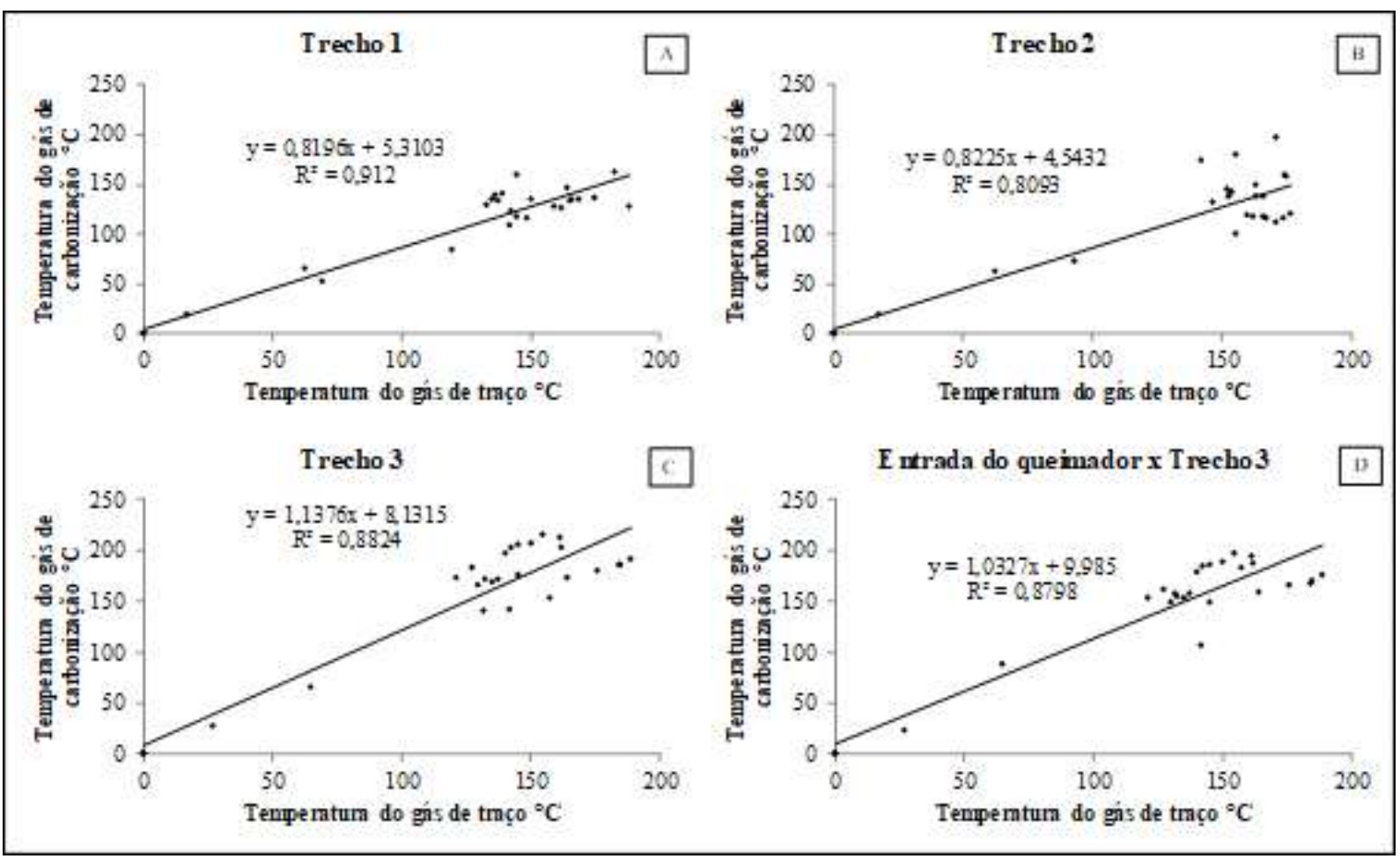

Figure 2 - Relationship between the average temperatures of the carbonization gases and traces gases obtained throughout the gas transportation network.

Figura 2 - Relação entre as temperaturas médias dos gases da carbonização e do gás de traço obtidas longo da rede de transporte dos gases. 
to propagate from particle to particle causing it to increase the carbonization gas temperature. Thus, the average heat exchange efficiency of the heater (trace gas pipe) was about $30 \%$ for the thermal gain of $50{ }^{\circ} \mathrm{C}$.

The average temperature of the carbonization gases in section 1 is lower than section 2 , and this is due to the different steps of the carbonization process. Section 2 had a greater number of kilns in the evaluated exothermic phase, and consequently, there was a difference in temperature between the two sections.

In section 3, there is an increase in the temperature of the carbonization gases when all gases are mixed, regardless of the stage of the furnaces. Section 3 is where all furnace gases in different phases of carbonization mix, and it occurs different tar concentrations, flows, and mainly different temperatures. It may lead to situations where the temperature of the mixture is quite lower than the higher flow temperature that participates of the mixture, causing the condensation of the tar and fires.

On the other hand, the average temperature of the trace gas along the GTN was above the average temperature of the carbonization gases. However, in section 3 the average carbonization temperature was $37.2^{\circ} \mathrm{C}$ higher than the trace gas temperature.

The average temperature at the burner chimney outlet for the trace gas was $218.35^{\circ} \mathrm{C}$ and it was released into the atmosphere at $125.2^{\circ} \mathrm{C}$, with a thermal loss of $93.15^{\circ}$ C. In other words, $57.34 \%$ of the thermal energy of the trace gas is released into the atmosphere through the ends of sections 1 and 2 .

The trace gas is heated on the GTN and can be blown into dryers and used in the artificial drying of the wood to be charred. Since the wood is artificially dried, a lower drying time and moisture content can be provided than when subjected to natural drying. It also entails significant gains with gravimetric yield, lower carbonization time, and on the quality of charcoal produced (Cardoso, 2015). Another important aspect of using wood with less water according to Canal et al. (2016), is the reduction of the amount of water vapor eliminated during the carbonization process and consequently a smaller amount of gases saturated with water and low calorific value, resulting in a better combustion efficiency of the carbonization gases. The use of a drier wood during the process leads the GTN even more efficient thermal changes (lower moisture in the process) and greater calorific value in the combusted gases

Revista Árvore. 2018;42(6):e420601

\subsection{Correlations between gas temperatures at different sampling points.}

The temperature at the bottom of the burner chimney (A4) had a positive correlation with the entrance temperature of the carbonization gases in the burner (A3). It also had a positive correction with the outlet temperature of the burner chimney (A5). Thus, the higher the entrance temperature of the carbonization gases, the higher the temperature of the gases in the bottom of the burner chimney and vice versa.

The average temperature of the trace gas (A6) in the sections had a positive correlation with the carbonization gases in the different runoff sections, which again shows that the trace gas kept the carbonization gas warm.

There was also a positive correlation between the average temperature of the trace gas at the outlet of the system (A7) and the average temperature of the carbonization gases in the sections (A2). This fact shows that the lower the temperature the gas was released into the atmosphere, more efficient is the heat transmission along the sections. Ferreira (2014), in a comparative study of thermal exchange between heat exchangers, confirmed the findings of this study. The increase in the thermal exchange efficiency is related to a greater flow of cold gases over hot gases. If the difference between the initial and final temperatures is short, the lower will be the thermal energy transmission between the gases in the GTN.

\subsection{Correlation between trace gas and carbonization gas}

The relationship between a trace gas temperature and a carbonization gas on section 1 was greater than on section 2, as respectively shown in Figure 2A and $2 \mathrm{~B}$. This fact is explained due to the synchronism of the kilns, as during the monitoring period of the temperatures of the GTN had a large number of ovens in the process of carbonization in section 1 . The difficulty of synchronism in furnaces provides a huge variation of temperature and also of gas flow, especially within the main gas transportation. So a charcoal production unit with more interconnected furnaces will minimize these problems by turning permanent a greater gas flow of higher calorific power send to the burner.

According to Figure 2D, which deals with the relationship between the average trace gas temperature in section 3 and the average carbonization gas entrance 
temperature in the burner, the regression coefficient obtained indicates that the increase of $1{ }^{\circ} \mathrm{C}$ in the trace gas temperature. This fact leads to an increase of around $1,032^{\circ} \mathrm{C}$ of the entrance temperature of the carbonization gas in the burner.

The analysis and findings of the results facilitate the subsidies of the engineering team of the system, which leads to an optimization of the project, making it even more technically and economically efficient.

\section{CONCLUSION}

The GTN along metallic and aerial pipes had the potential to be used in UPC's (Charcoal Producing Units).

The use of trace gas to maintain a high temperature in carbonization gas transportation was efficient and provided an increase in carbonization gas temperature of about $50^{\circ} \mathrm{C}$.

Therefore, the use of trace gas in the GTN is a thermally efficient alternative to drain the carbonization gases, requiring small operational adjustments in the design of the settings, operation, and maintenance, guaranteeing the air-tightness of the process.

The proposed GTN provides significant and efficient gains to the integrated processes of charcoal production in conventional masonry ovens, such as carbonization, gas transportation, burning and utilization of heat for cogeneration of electricity and wood drying, attached or not to monitored and automated systems. Still, they represent an efficient way of guarantee good environmental conditions in the carbonization plants, avoiding the formation of undesirable liquid effluents and potentially contaminating soil and local aquifers.

The subsidies to the engineering projects for calculation and size optimization in each situation will lead to an improvement of the project from the technical and economic points of view.

\section{ACKNOWLEDGMENTS}

To the Research and Design Program of ANEEL, to ArcelorMittal Bioflorestas and Cemig for the funding and support for the project. Also, to the Coordenação de Aperfeiçoamento de Pessoal de Nível Superior (Capes), to the CNPq for the productivity grant and the Foundation for Research Support of the State of Minas Gerais (FAPEMIG), for the financial support and the granting of scholarships. And to all the researchers who contributed directly and indirectly to this work. In Memoriam of the researcher Bartholomeu Amaral.

\section{REFERENCES}

Associação Brasileira de Produtores de Florestas Plantadas - ABRAF. 2012. Anuário estatístico da ABRAF: ano base 2011. Brasília, DF: 2012. 130p.

Cardoso MT. Secagem da madeira em toras com gases combustos do sistema forno-fornalha [tese]. Viçosa, MG: Universidade Federal de Viçosa; 2015.

Cardoso MT, Damásio RAP, Carneiro ACO, Jacovine LAG, Vital BR, Barcelos DC. Construção de um sistema de queima de gases da carbonização para redução da emissão de poluentes. Cerne. 2010;16:115-24.

Canal WD, Carvalho AMML, Carneiro ACO, Vital BR, Pereira BLC, Donato DB. Efeito do teor de umidade da madeira na emissão de gases de efeito estufa no processo de carbonização. Scientia Florestalis. 2016;44(112):831-40.

Carneiro ACO, Lana AQ, Oliveira AC, Pereira BLC, Salles TT. Estudo da viabilidade técnica e econômica da produção de carvão vegetal em fornos circulares com baixa emissão de poluentes. Viçosa, MG: Centro de Pesquisas em Economia Aplicada-CEPEA/ESALQ; 2012.

De Paula DHV, Cunha LG. Economia de energia isolamento térmico. FAZU em Revista. 2013(10):49-54.

Ferreira AC. Estudo comparativo da troca térmica em Trocadores de calor dos tipos casco/tubos e de placas. Unoesc \& Ciência - ACET. 2014(Esp):57-66.

Hildebrandt JL, Battistel OL. Modelo para transmissão de calor em Condutor cilíndrico. Disciplinarum Scientia. Série: Ciências Exatas. 2001;2(1):133-51.

Tipler P. Física: gravitação, ondas e termodinâmica. $3^{a}$.ed. Rio de Janeiro: LCT; 1995. 